\title{
Chemical Characterization of the Essential Oil of Syzygium Aromaticum and its Antimicrobial Activity Against A Probiotic Lactobacillus Acidophilus
}

Jhunior Abrahan Marcía Fuentes, MSc.

National University of Agriculture,

Faculty of Technological Sciences, Honduras

Ismael Montero Fernandez, PhD

University of Extremadura, Departament of Organic and Inorganic Chemistry, Spain

Ricardo Santos Aleman, MSc

Louisiana State University Agricultural Center,

School of Nutrition and Food Science

Selvin Antonio Saravia Maldonado, MSc

National University of Agriculture,

Faculty of Earth Sciences and Conservation, Honduras

Leonardo Flores Roger, MSc

National University of Agriculture,

Faculty of Technological Sciences, Honduras

Nelys Herrera Funez, MSc

National University of Agriculture, Faculty of Sciences, Honduras

Leonardo Antonio Chavarría, MSc

National University of Engineering,

Faculty of Chemical Engineering, Nicaragua

Aryana Kayanush, PhD

Louisiana State University Agricultural Center,

School of Nutrition and Food Science

Doi:10.19044/esj.2020.v16n15p33～URL:http://dx.doi.org/10.19044/esj.2020.v16n15p33

\section{Abstract}

Eugenol is the main constituent of clove (Syzygium aromaticum) essential oil. It is liquid and oily in consistency, light yellow, with a characteristic aroma, slightly soluble in water and soluble in alcohol. In addition, it is considered an essential oil of high antibacterial, antifungal, and antioxidant capability. Studies related to its effect on probiotic bacteria are scanty. The objective of this research was to determine the chemical composition of clove essential oil and the antimicrobial influence of clove 
extract from clove on the growth of Lactobacillus acidophillus. Among the main constituents in clove essential oil, eugenol stands out with $79.47 \%, \beta$ cariophilene with $7.67 \%$ and $\alpha$-humulene with $2.65 \%$. L. acidophilus was inoculated in MRS Sorbitol agar containing 0\%, 0.1, 0.50, 1, 2 and 3\% essential oil and incubated for 0,24 and $48 \mathrm{~h}$. Pour plates were incubated anaerobically at $35^{\circ} \mathrm{C} \pm 1{ }^{\circ} \mathrm{C}$ for $48 \mathrm{~h}$. A colony counter was used to enumerate bacteria. The clove extract showed an inhibitory effect against L. acidophillus from concentrations greater than 1\%, but at concentration less than $1 \%$ essential oil did not adversely influence growth of L. acidophilus. The inoculation time at $0 \mathrm{~h}$ showed significantly highest counts compared to $24 \mathrm{~h}$ and $48 \mathrm{~h}$ which had counts not significantly different from each other. Although counts were lowered, L acidophilus survived the $48 \mathrm{~h}$ exposure. Clove essential oil use and L. acidophilus probiotic benefit can both be had when essential is used at less than $1 \%$.

Keywords: Clove, Natural Products, Antimicrobial, Eugenol

\section{Introduction}

There is increasing interest in bioactive compounds obtained from essential oils from plants to treat microbial infections caused by antibiotic resistance (Cui et al., 2019). On the other hand, essential oils are increasingly booming in order to replace synthetic preservatives in foods in favor of natural alternatives (Simas et al., 2017). Plants are considered as the most important source of chemical compounds that exists (Mesquita and Tavares, 2018).

The essential oil consists of secondary metabolites, including terpenes and sesquiterpenes with biological potential (Cunha et al., 2005). The quantity and composition of essential oils, according to Costa (2008), vary in terms of the genetic and physiological levels of the plant, as well as depending on the conditions of cultivation, harvest and post-harvest treatment as well as environmental factors.

Among the essential oils extracted from medicinal plants, the clove (Syzygium aromaticum) stands out. Along with other medicinal plants, this essential oil was used in World War II to heal soldiers wounded in combat (Cunha and Roque, 2013). Clove (Syzygium aromaticum) is a plant characterized as one of the aromatic spices best known for its medicinal, antibacterial, antioxidant properties and for its use as a flavoring in foods for human consumption (Rivas et al., 2015).

In its chemical composition, clove has numerous secondary metabolites with biological activity. These compounds include phenolic compounds, flavonoids, hydroxybenzoic acids and hydrokinetic acids, with eugenol being the main constituent with concentrations that can vary between

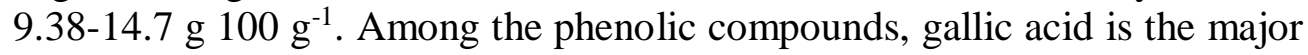


compound (Cortés-Rojas et al., 2014) Chemical composition of clove essential oil, between $80-90 \%$ is eugenol, $15 \%$ of eugenol acetate and between $5-12 \%$ of beta caryophyllene (Alma et al., 2007).

The other important compound found in this essential oil in concentrations of up to $2.1 \%$ is alpha humulene. Additonally, other volatile compounds present in lower concentrations are beta pinene, limonene, farnesol, benzaldehyde, 2-heptanone and ethyl hexanoate (Aguilar and Malo, 2013). According to the WHO, clove essential oil is considered safe when consumed in concentrations of $1500 \mathrm{mg} \mathrm{kg}^{-1}$ or lower (Gülçin et al., 2012).

Probiotics are live microorganisms that have beneficial effects on the health of humans and animals (Torres et al., 2011). Lactic acid bacteria, which include the Lactobacillus and Bifidobacterium species have been used for food preservation by fermentation for many of years and can potentially have a dual function, acting as agents for food fermentation and health benefits, (Torres $e t$ al., 2011, Aryana and Olson 2017). L. acidophillus is of great industrial importance, as it is used in various lactic fermentation processes (yogurt and cheese). L. acidophillus is also involved in the manufacture of products derived from vegetables. Probiotics must remain viable during processing, storage and transmission through the gastrointestinal tract (da Silva et al., 2015).

Clove is a very common plant and its oil can be easily extracted, it could be used in the-manufacture of nutraceutical foods. There are very few reports on the synergistic and antagonistic effects of clove extracts on probiotic bacteria (Pastrana et al., 2017). The objective of this work was to determine whether or not there was antimicrobial activity of clove essential oil, mainly due to eugenol as a major constituent in the growth of $L$. acidophillus,

\section{Material and method:}

Essential oil extraction

Approximately $1 \mathrm{~kg}$ of cloves, were purchased in the town of Catacamas, department of Olancho (Honduras) was washed with distilled water for the removal of any type of impurity and then placed in a hydrodistillation flask with distilled water in a Clevenger type apparatus where hydrodestilation was performed over a period of 4 hours. It was subsequently dried over anhydrous sodium sulfate and stored in an amber bottle until it was time to perform the analyzes.

\section{Essential oil analysis by gas chromatography}

The essential oil was analyzed on a HP 7820A Gas Chromatograph (GC) equipped with a flame ionization detector (FID) using a capillary column (HP5 $30 \times 0.32 \mathrm{~mm} \times 0.25$ microns, Agilent $)$. Column temperature: $50{ }^{\circ} \mathrm{C}(0$ 
min) to $3{ }^{\circ} \mathrm{C} \min ^{-1}$ to $230{ }^{\circ} \mathrm{C}$. Gun: $250{ }^{\circ} \mathrm{C}$ Split (1:30). FID Detector: $250{ }^{\circ} \mathrm{C}$. Carrier gas: hydrogen to $3 \mathrm{ml} \mathrm{min}{ }^{-1}$. Vol injection: $1 \mu 1$. Essential oil was diluted to $1 \%$ in chloroform. Data acquisition software used was Compact EZChrom Elite (Agilent). The quantitative analysis was performed using standard areas from the chromatograms obtained by GC-FID.

Subsequently, to quantify the different constituents, a CG-MS with Column: Rxi-1MS $92330 \mathrm{~m} \times 0.25 \mathrm{~mm} \times 0.25$ microns (Restek) was used. Column Temp: $50^{\circ} \mathrm{C}(3 \mathrm{~min}), 3^{\circ} \mathrm{C} \mathrm{min}^{-1}$ to $250^{\circ} \mathrm{C}$. Injector: $250^{\circ} \mathrm{C}$ Split (1:10), GC-MS interface at $250^{\circ} \mathrm{C}$. MS detector (electron impact at $70 \mathrm{eV}$ ) temperature was $250^{\circ} \mathrm{C}$. Carrier gas: Helium up to $1.5 \mathrm{ml} \mathrm{min}^{-1}$. Vol injection: $1 \mu \mathrm{l}$. Essential oil was diluted to $0.1 \%$ in chloroform. Data acquisition software used was GC-MS Solution (Shimadzu) with NIST11 library. Identification of peaks was made by comparison of the mass spectra obtained by GC-MS spectra with the NIST11 library and also by comparing the Kovats indices calculated by GC-FID and literature data.

\section{Antimicrobial activity of the essential oil of $S$. aromaticum in the growth of $L$. acidophilus.}

This research was carried out at the Biotechnology Institute of the National University of Agriculture (Honduras).

MRS broth powder was incorporated into distilled water and autoclave at $121{ }^{\circ} \mathrm{C}$ for 15 minutes to make MRS broth. A $10 \%$ sorbitol solution, filter sterilized with Nalgene membrane, was prepared. This solution (10\%) was added to the MRS broth $(90 \%)$ to make sorbitol MRS broth. Essential oil at concentrations of $0,0.1,0.50,1,2$ and $3 \%(\mathrm{w} / \mathrm{v})$ was incorporated into sorbitol-MRS broth. This essential oil sorbitol-MRS broth was inoculated with L. acidophilus and incubated at 0,24 and $48 \mathrm{~h}$. Serial dilutions were prepared. Pour plates were incubated anaerobically at $35^{\circ} \mathrm{C} \pm 1{ }^{\circ} \mathrm{C}$ for $48 \mathrm{~h}$. after which colonies were counted.

\section{Statistical Analysis}

The data was analyzed in the SPSS software, version 25.0, and means were separated using Tukey test and significant differences were determined at $\mathrm{P}<0.05$.

\section{Results and discussion:}

Identification of the chemical constituents of Syzygium aromaticum. In table 1 , the chemical constituents in the essential oil of $S$. aromaticum are presented, a total of 11 constituents being undefined. 
Table 1. Identification of constituents not essential oil de S. aromaticum.

\begin{tabular}{lll}
\hline Number & Constituent & $\%$ \\
\hline 1 & Eugenol & $79.47 \pm 0.3$ \\
2 & Copaene & $1.76 \pm 0.05$ \\
3 & $\alpha$-humulene & $2.65 \pm 0.04$ \\
4 & $\beta$-cariofilene & $7.67 \pm 0.10$ \\
5 & Eugenol acetate & $1.32 \pm 0.02$ \\
6 & Cariofilene oxide & $0.65 \pm 0.03$ \\
7 & 2-heptanone & $0.24 \pm 0.01$ \\
8 & Humulene & $2.48 \pm 0.04$ \\
9 & Calamene & $0.37 \pm 0.03$ \\
10 & calacorene & $0.45 \pm 0.04$ \\
11 & 2-etil-hexanoic acid & $0.12 \pm 0.01$ \\
Other & & $2.82 \pm 0.05$ \\
\hline
\end{tabular}

$*$ Results in triplicate describe the mean \pm standard deviation

In table 1 , a total of 11 chemical constituents were identified in the essential oil of $S$. aromaticum, the majority being eugenol with $79.47 \%, \beta$ cariophilene with $7.67 \%, \alpha$-humulene with $2.65 \%$, humulene with $2.48 \%$ and copaene with $1.76 \%$.

The concentration of eugenol found in this work as a major compound is in accordance with the values indicated by Affonso et al., (2012), who reported concentration of eugenol between $82.47-90.41 \%$ in the essential oil of the different parts of the plant. The next major compound found was $\beta$ cariofilene. Since eugenol is the major component of the essential oil, it is the one that contributes most to the antifungal and antibacterial action (Pereira et al., 2008).

\section{Inhibitory effect of eugenol of Lactobacillus acidophilus.}

The eugenol from $S$. aromaticum, showed a significant inhibitory effect against $L$. acidophillus cells from 0.5 to $3 \%$, with $3 \%$ having the greatest inhibitory effect. However, concentration of $0.1 \%$ was similar to the control (Figure 1). 


\section{Survival of Lactobacillus \\ acidophilus}

in the presence of essential oil

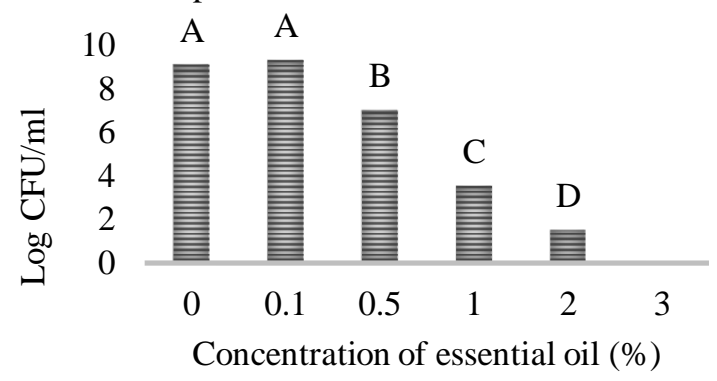

Figure 1. Tukey media grouping between treatments $(\mathrm{p} \leq 0.05)$

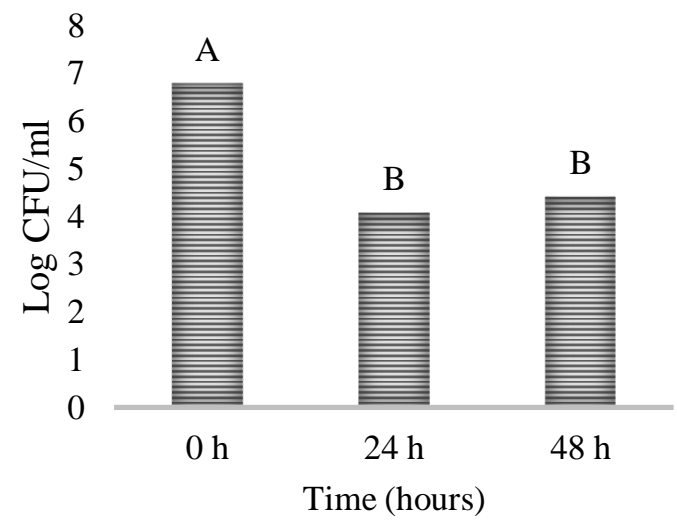

Figure 2. Survival of L. acidophilus in the presence of essential oil during different times of inoculation.

In Figure 2, the relationship between inoculation times at 0, 24 and 48 hours with respect to the effect of clove essential oil on the survival of $L$. acidophilus is presented. These results indicate that at 0 hours, the counts were significantly high. However, a greater inhibitory effect was observed between 24-48 hours, without showing significant differences in the optimal quantification times. These results coincide with those provided by Gonzalez (2002), which indicates the effect that eugenol has, the main constituent of the essential oil in the inhibitory effect of fungi and bacteria. 


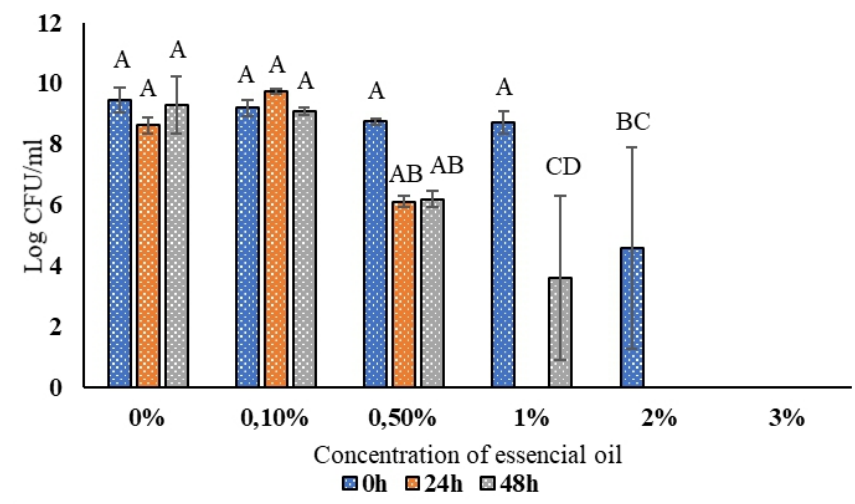

Figure 3. Survival of L. acidophilus in the presence of essential oil during different times of incubation.

Clove oil, which contains a high eugenol $(79.47 \%)$ content, has not only shown antimicrobial activities in Lactobacillus acidophilus but also having wide spectra of antimicrobial effects against enterobacteria (Burt and Reinders 2003; Nanasombat and Lohasupthawee 2005). Park et al. (2007), pointed out that clove essential oil has always been used due to its properties as an antimicrobial agent, given its efficiency in inhibiting pathogenic microorganisms, being one of the properties of said oil that has been little explored until now. Since the main inhibitory component of clove oil is believed to be eugenol (Jayatilaka et al. 1995; Della Porta et al. 1998; Bullarman et al. 2006; Sukutta et al. 2008), clove, also, has been report to be effective against molds and yeasts (Lopez-Malo et al. 2002). The essential oil extracted from aromatic plants have been shown to have antibacterial (Gianneanas et al. 2003), antifungal (Janatan et al. 2003), antioxidant activities (Bostoglou et al. 2004). The action of the microbial inhibition of eugenol may be related to the rupturing of the membrane or the inactivation of enzymes and genetic materials (Wendakdoon and Sakaguchi, 1993).

\section{Conclusion}

Clove essential oil has different bioactive compounds in its chemical composition, mainly in eugenol as a major constituent. Said constituent gives the essential oil medicinal properties being demonstrated in this work. Essential oil concentration of $0.5 \%$ is optimum as it can have essential oil use with $L$. acidophilus presence for probiotic effect.

\section{References:}

1. Alma, M.H.; Ertras, M.; Nitz, S.; Kollmannsberger, M. (2007). Chemical Composition and Content of Essential oil from the Bud of 
Cultivated Turkish clove (Syzygium aromaticum L.). BioResources, 2(2):265-269.

2. Affonso, R.S.; Rennó, M.N.; Slana, G.B.C.A.; França, T.C.C. (2012). Chemical and Biological Aspects of the Essential Oil of Indian cloves. Revista Virtual de Química, 4 (2):146-161.

3. Aguilar, A.; Malo, A. (2013). Extracts and essential oils of clove Syzygium aromaticum and its potential application as an antimicrobial agent in food. Selected subjects of Food Engineering, 7 (2): $35-41$.

4. Aryana, K.J. and Olson D. 2017. A 100-Year Review: Yogurt and other cultured dairy products. Journal of Dairy Science, 100: 998710013.

5. Bostoglou N.A., Christaki E., Florou-paneri P., Giannenas I., Papageorgiou G. and Spais A.B. (2004). The effect of a mixture of herbal essential oils or $\alpha$-tocopheryl acetate on performance parameters and oxidation of body lipid in broilers. South African J. Anim. Sci, 34 (1): 52-61.

6. Bullarman, L.B., Lieu, F.Y. and Seier, S.A. 2006. Inhibition of growth and aflatoxin production of cinnamon clove oils: Cinnamic aldehyde and eugenol. J. Food Sci, 42 (1): 1107-1109.

7. Burt, S.A. and Reinders, R.D. 2003. Antibacterial activity of selected plant essential oils against Escherichia coli O157: H7. Lett. Appl. Microbiol, 36 (1): 162-167.

8. Cortés-Rojas, D.F., de Souza, C.R.F., Oliveira, W.P. Clove: (Syzygium aromaticum). Asian Pacific Journal of Tropical Biomedicine, 4(2):90-96.

9. Costa, A. G. (2008). Desenvolvimento vegetativo, rendimento e composição do óleo essencial de Patchouli após adubação nitrogenada. Curitiba: Universidade Federal do Paraná online in < http://www.seer.ufu.br/index.php/biosciencejournal/article/view/1797 $7 / 13753>$

10. Cui, H., Zhang, C., Li, C., and Lin, L. (2019). Antibacterial mechanism of oregano essential oil. Industrial Crops and Products, 139: 111498

11. Cunha, A. P. \& Roque, O. R. (2013). Aromaterapia - Fundamentos e Utilização, Lisboa, Fundação Calouste Gulbenkian.

12. Cunha, A. P., Cavaleiro, C.; Salgueiro, L. (2005). Fármacos aromáticos (Plantas aromáticas e óleos essenciais). In: Cunha, A. P. d. (ed.) Farmacognosia e Fitoquímica. $2^{\mathrm{a}}$ ed. Lisboa Fundação Caloust Gulbenkian p.339 - 401.

13. Da Silva, V.T.; Braga, C.; de Oliveira, Z.J. (2015). Indirect normative conflict: conflict that depends on the application domain. 17 th 
International Conference on Enterprise Information Systems. V. 1, 452-461.

14. Della porta, G., Taddeo, R., D'urso, E. and Reverchon, E. (1998). Isolation of clove bud and star anis essential oil by supercritical $\mathrm{CO}_{2}$ extraction. Lebensm. Wiss. Technol. 31(1): 454-460

15. Gianneanas I., Florou Paneri P., Papazahariadou M., Cheristaki E., Bostoglou N.A. and Spais A.B. (2003). Effect of dietary supplementation with oregano essential oil on performance of broilers after experimental infection with Eimeria tenel. Br. Poult. Sci, 57(1): 99-106.

16. Gülçin I, Elmastaş M, Aboul-Enein H. Y. (2012). Antioxidant activity of clove oil-A powerful antioxidant source. Arab J Chem, 5(4): 489499.

17. González Escobar, Raimara. (2002) Eugenol: pharmacological and toxicological properties. Advantages and disadvantages of its use. Cuban Journal of Stomatology, 39 (2): 139-156.

18. Flores Soler, R. \& Aryana, K. (2018). Influence of cloves on viability of Lactobacillus acidophilus. School of Animal and Food Sciencie. Louisiana State University. 6 p.

19. Janatan I.B., Yassin M.S.M., Chin C.B., Chen L.L. and Sim N.L. (2003). Antifungal activity of the essential oils nine zingiberaceae species. Br. Poult. Sci. 41 (1): 392-397.

20. Jayatilaka, A., Poole, S.K., Poole, C.F. and Chichila, T.M.P. 1995. Simultaneous micro steam distillation/solvent extraction for the isolation of semivolatile flavor compounds from cinnamon and their separation by series coupled-column gas chromatography. Anal. Chim. Acta 302 (1): 147-162.

21. Lopez-malo, A., Alzamora, S.M. and Palou, E. 2002. Aspergillus flavus dose-response curves to selected natural and synthetic antimicrobials. Int. J. Food Microbiol, 73 (1): 213-218.

22. Mesquita Ulliane de O y Tavares-Martins A. (2018). Ethnobotany of medicinal plants in the community of Caruarú, Isla del Mosqueiro, Belém-PA, Brazil. Latin American and Caribean newsletter of medicinal and aromatic plants, 17 (2): 130 - 159.

23. Nanasombat, S. and Lohasupthawee, P. 2005. Antimicrobial activity of crude ethanolic extracts and essential oils of spices against salmonellae and other enterobacteria. KMITL Sci. Technol. J, 5(1): 527-538.

24. Oliveira, R. A., Guerra de, Lima, E. O.; Vieira, W. L.; Freire, K. R.; Luna, T. V. N., Lima, I. O.; Souza, E. L., Toledo, M. S.; \& Silva-Filho, R. N. (2006). Estudo da interferência de óleos essenciais sobre a 
atividade de alguns antibióticos usados na clínica. Revista Brasileira de Farmacognosia, 16(1), 77-82.

25. Pastrana Puche, Y., Durango Villadiego, A., Acevedo Correa, D. (2017). Effect of cloves and cinnamon on pathogens. Biotecnología en el Sector Agropecuario y Agroindustrial, 15 (1): 56-65.

26. Park, M.J.; Gwak, K.S.; Yang, I.; Choi, W.S.; Jo, H.J.; Chang, J.W.; Jeung, E.B.; Choi, I.G. (2007). Antifungal activities of the essential oils in Syzygium aromaticum (L.) Merr. Et Perry and Leptospermum petersonii Bailey and their constituents against various dermatophytes. The J. Microbiol. 45(1):460-465.

27. Pereira, A.A.; Cardoso das Graças, M.; de Morais, L.R.; de Guimaraes, A.R.; de Lima, L.G. \& Salgado, A.P.S.P. (2008). Caracterização química e efeito inibitório de óleos essenciais sobre o crescimento de Staphylococcus aureus e Escherichia coli. Ciência e Agrotecnologia, 32(3):887-93.

28. Rivas, K.; Rivas, C.; Gamboa, L. (2015). Chemical composition and antimicrobial activity of basil essential oil (Ocimum basilicum L.). Rev., Multiciences, 15 (3): 281-289.

29. Simas, D.L.R.; de Amorin, SHBM.; Goular, F.R.V.; Alviano, C.S.; and da Silva, A.J.R. (2017). Citrus species essential oils and their components can inhibit or stimulate fungal growth in fruits. Industrial Crops and Products. 98(1): 108-115.

30. Sukatta, U., Haruthaithanasan, V., Chantarapanont, W., Dilokkunanant, U. and Suppakul, P. 2008. Antifungal activity of clove and cinnamon oil and their synergistic against postharvest decay fungi of grape in vitro. Kasetsart J. (Nat. Sci.), 42(1):169-174.

31. Torres, R.; Peregrina, R.; Gonzales, M.; Aznar, E.; Gonzales, R. (2011). Probiotics; A new universal concept for health. Editorial Universidad De Guadalajara, ISBN 978-607-9114-01-5. Guadalajara, Jalisco, Mexico.

32. Wendakdoon CN, Sakaguchi M.(1993). Combined effect of sodium chloride and clove on growth and biogenic amine formation of Enterobacter aerogenes in mackerel muscle extract. J Food Protect, 56(1):410-13. 